\title{
Aspects of Winter Temperatures in Interior Alaska
}

\author{
N. A. STRETEN 1
}

\begin{abstract}
The variation of monthly mean winter temperatures in the Yukon and Tanana Valleys is described in relation to the region's topography. Extreme cold and warm months are identified by consideration of the 66 years of observations at Tanana. Day-to-day temperature variations in these months at different stations reveal the influence of topographic barriers in affecting warming trends. Large-scale circulation factors associated with extreme years are described.
\end{abstract}

RÉSUMÉ. Aspects des températures hivernales en Alaska intérieur. L'auteur décrit les variations des températures mensuelles moyennes hivernales des vallées du Yukon et de la Tanana, en relation avec la topographie de la région. Il identifie les mois de froid extrême et de chaleur extrême à partir des observations recueillies en 66 ans. Pour ces mois extrêmes, les variations thermiques au jour le jour aux différentes stations révèlent l'influence des barrières topographiques sur les tendances au réchauffement. L'auteur décrit enfin les facteurs de circulation à grande échelle qui sont associés aux années extrêmes.

РЕЗЮМЕ. Характеристика зимних температур во өнутренних районах Аляски. Дается описание колебаний среднемесячных вимних температур в долинах рек Юкон и Танана в зависимости от характера местности. Наиболее холодные и теплые месяцы установлены по данным многолетних наблюдений в долине реки Танана. Суточные колебания температур в эти месяцы, отмеченные на различных станщиях, указывают на роль топографических барьеров в развитии потеплений погоды.

\section{INTRODUCTION}

The interior basin of Alaska lying between the climatic divides of the Brooks and Alaska Ranges appears in mean climatic maps as the location of the most extensive region of extremely low mean winter temperatures in the United States and provides a striking contrast to the milder winter temperature regime of both south central Alaska and the region on the Arctic slope of the Brooks Range. Mean maximum and minimum temperatures for January (Watson 1959) reveal clearly this "cold pole" extending over the Yukon and Tanana valleys and centred on the Yukon Flats surrounding Fort Yukon.

The winter temperature regime may be investigated more closely by examination of the topography of the region (Fig. 1) in relation to observed mean temperatures at a number of stations. It is immediately clear that the lowest mean temperatures in the winter months occur in general in the valley bottoms with warmer temperatures on the higher ground. The strong semi-permanent winter inversions which are characteristic of all polar and sub-polar winter environments, have been measured at a number of locations in central Alaska. Much of the classical study of the physical processes involved in inversion development over

${ }^{1}$ Geophysical Institute, University of Alaska, College, Alaska. 


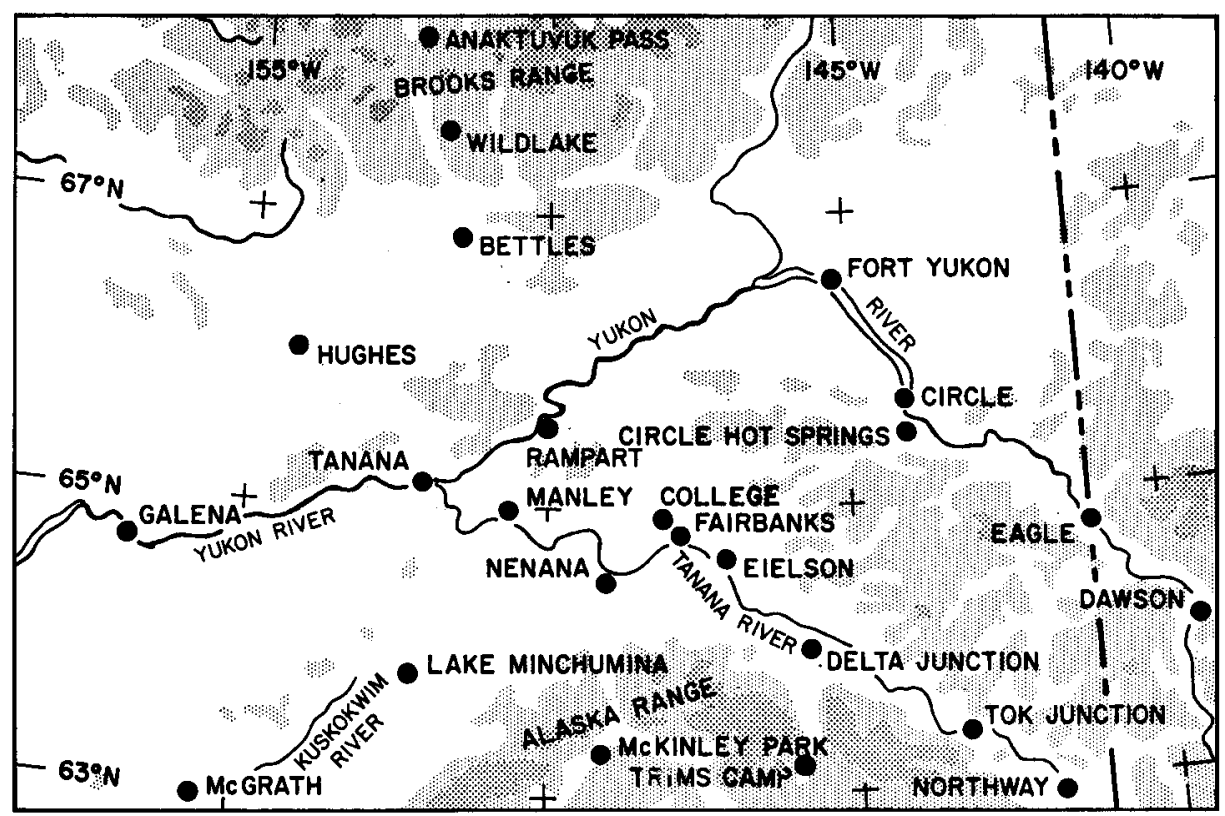

FIG. 1. Topography of interior basin of Alaska showing meteorological observing stations (light shading, land over 3,000 feet; heavy shading over 6,000 feet).

snow- and ice-covered terrain was based on observations at Fairbanks (Wexler 1936). More recent work on the micrometeorology of inversions has, in general, been based on observations over such topographically featureless regions as the Arctic Ocean (Vowinckel and Orvig 1967) and on an antarctic ice shelf (Liljequist 1964). The present study attempts to investigate what climatic information can be obtained from the gross long-term surface data for interior Alaska.

Detailed measurements quoted by Benson (1965) show inversions of up to $54^{\circ} \mathrm{F}$. in $100 \mathrm{~m}$. in extreme cases at Fairbanks. However, from the large scale climatological viewpoint the mean inversions in the colder months may be seen in the differences in surface temperatures at the pairs of stations in Fig. 2 for different parts of the valleys at varying elevations.

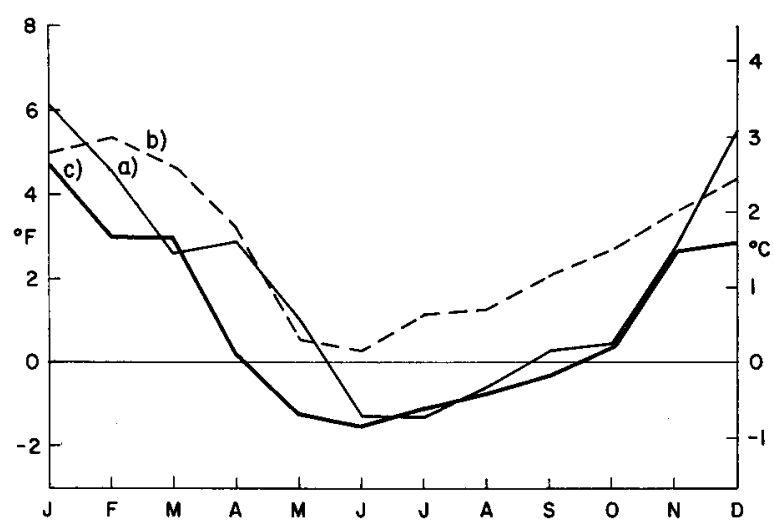

FIG. 2. Monthly mean temperature differences between pairs of stations in interior Alaska based on 10 years of data (1951-1960). a) Circle Hot Springs (1,000 feet) - Fort Yukon (419 feet); b) Lake Minchumina (701 feet) Tanana (232 feet); c) College Magnetic Observatory (621 feet) - Fairbanks Airport (436 feet). 


\section{VARIABILITY IN TIME AND LOCATION}

An outstanding feature of the monthly mean temperatures in winter is the marked variationfrom year to year. This may be seen in the long-term temperature measurements for December, January, and February at Tanana (Fig. 3). This station (elevation 232 feet) is fairly representative of the valleys, as it is located at the confluence of the Tanana and Yukon rivers; it possesses a reasonably consistent series of observations maintained in an essentially unchanging environment since 1903. The relation between mean temperatures at Tanana and Fairbanks is quite close so that for the few months of missing record at the former station, the value of mean temperature may be fairly accurately assessed from the Fairbanks data. Such estimates are shown with the actual Tanana observations in Fig. 3.
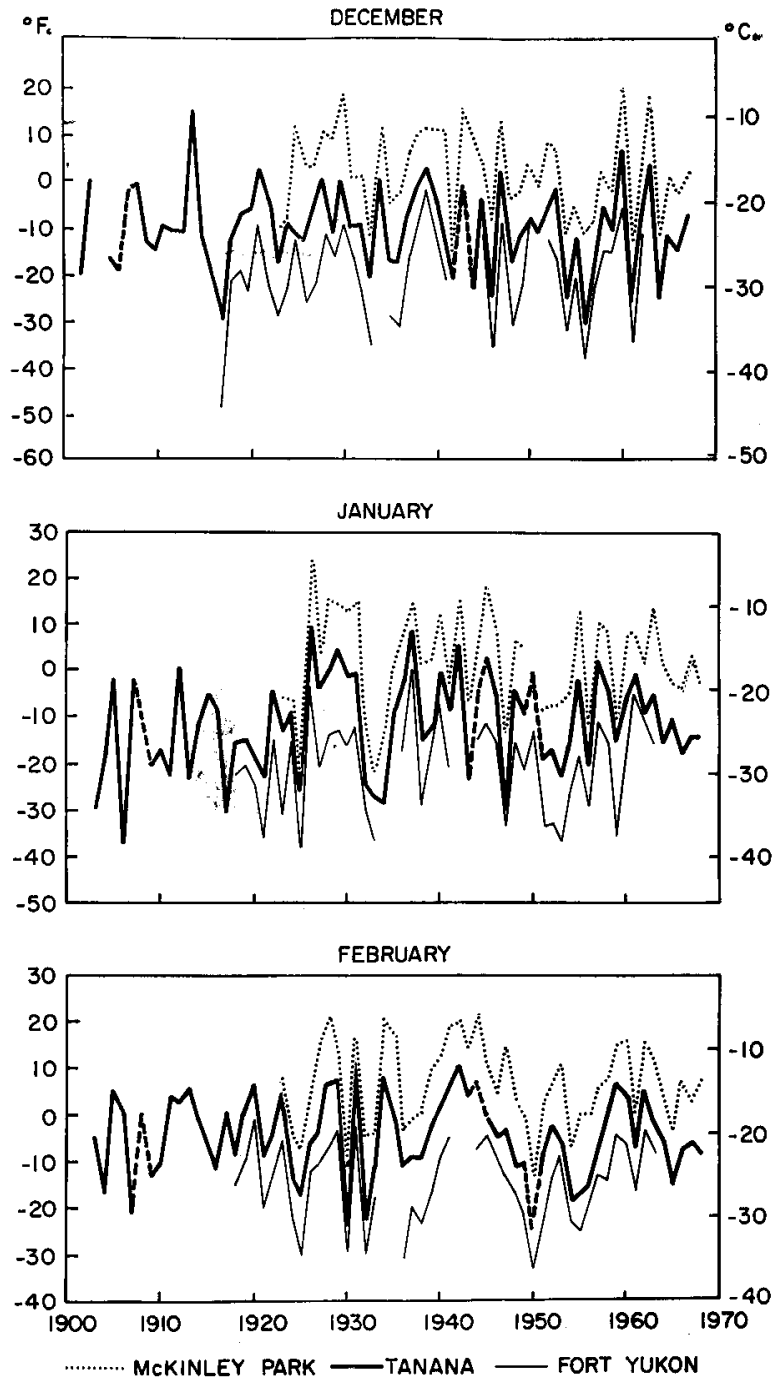

FIG. 3. Monthly mean temperatures for December, January, and February at Tanana, McKinley Park, and Fort Yukon for all years of record. The broken portions of the Tanana curve represent monthly mean temperatures for months of missing data estimated by comparison with long term data for Fairbanks and Tanana. 
By way of contrast, in Fig. 3 the available corresponding values of mean temperature for the same months are shown for the 2 stations that have a considerable length of record and which record respectively the coldest and warmest mean temperatures in the region: Fort Yukon (elevation 419 feet) and McKinley Park (elevation 2042 feet).

In general, the correspondence in warm and cold months at the 3 locations is quite close as might be inferred from the essential climatic unity of the region and by consideration of the dimensions of the synoptic scale features influencing the winter climate which will be mentioned later. Some appreciation of the variation from the monthly mean temperatures in winter at a representative station may be gained by referring to Table 1 .

Well-defined below-normal temperatures are seen to be most frequent in January, the extreme temperature of $26.2 \mathrm{deg}$. F. below normal occurring in January 1906. Above-normal temperatures are most common in February, but the extreme departure of $24.7 \mathrm{deg}$. F. above normal occurred in December 1914. Extreme high and low departures of greater than $20 \mathrm{deg}$. F. have also been most frequent in December.

TABLE 1. Percentage of Winter Months at Tanana with Monthly Mean Temperature Above or Below Specified Departures from the 30 Year (1931-1960) Normal. (Based on 66 Years of Record, 1902-1968.)

\begin{tabular}{lcccccc}
\hline & $\begin{array}{c}\text { Normal Mean } \\
\text { Memperature }\end{array}$ & $\begin{array}{c}\text { Below Normal Departure } \\
\text { Tenth }\end{array}$ & 10 deg. F. $\geq 15$ deg. F. $\geq 20$ deg. F. $\geq 10$ deg. F. $\geq 15$ deg. F. $\geq 20$ deg. F. \\
\hline Dec. & -9.9 & 14 & 8 & 3 & 15 & 3 \\
Jan. & -10.5 & 20 & 11 & 2 & 12 & 5 \\
Feb. & -4.6 & 17 & 6 & 2 & 17 & 2 \\
\hline
\end{tabular}

To show the variations over the whole region in extreme cases, two Decembers, those of 1956 and 1960, have been examined. December 1956 is the coldest month on record at Tanana with a mean temperature of $-30.6^{\circ} \mathrm{F}$. and December 1960 with a mean temperature of $+6.4^{\circ} \mathrm{F}$. the warmest December since the record of $+14.3^{\circ} \mathrm{F}$. in 1914 when few observations at other stations are available.

Fig. 4 shows the isotherms of mean temperature for these extreme months. It should be noted that the analyses differ slightly from those published by the U.S. Weather Bureau for the same months as an attempt has been made to take account of the larger topographic differences over the valley so far as is possible on a map of this scale. In both situations the extreme cold region of the Yukon flats shown by the observations at Fort Yukon and Circle is apparent. The region of lowest temperature lies along the valley of the Yukon and the Tanana with the exception of a considerably warmer region near Delta Junction. This warmer (though higher wind-chill) region is associated with the stronger winds, which are a feature of the climate near the major pass in the Alaska Range (Mitchell 1956). These winds inhibit the formation of long-lived temperature inversions in this area and further contribute to higher winter temperatures by advection of warmer air from south of the range. 


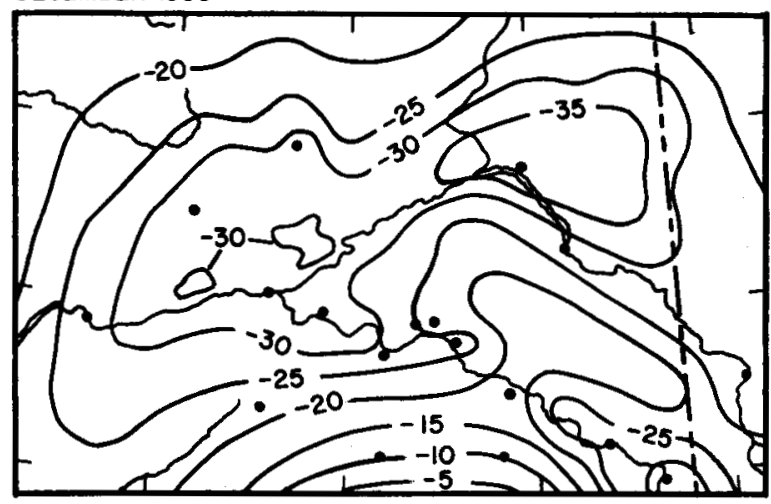

FIG. 4. Isotherms of monthly mean temperature in interior Alaska.

\section{DECEMBER 1960}

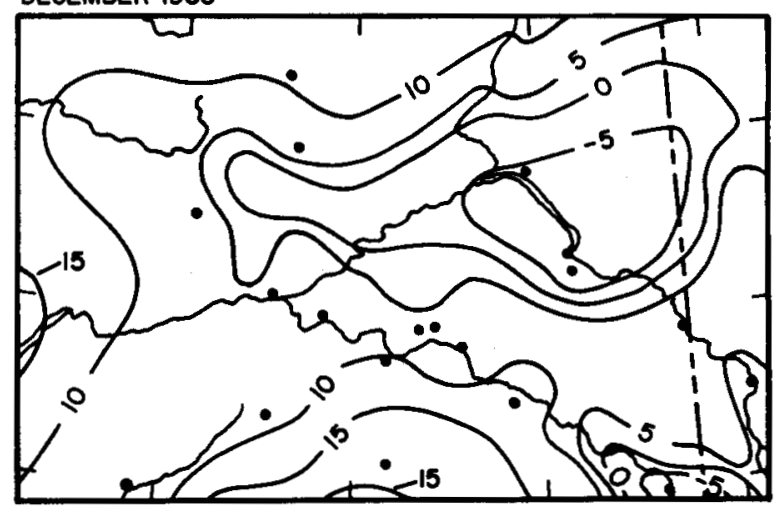

Examination of the daily maximum and minimum temperatures for the colder months of the Tanana record (e.g., January 1925, December 1917, and December 1956), reveals significant differences in the pattern of behaviour at different sites in the region. In all the months examined, it was apparent that certain warming influences which reached such stations as McKinley Park, Tanana, Fairbanks, and even Bettles frequently failed completely to penetrate to the Yukon flats and the temperature at Fort Yukon and Circle continued to fall. A typical example of this is shown in Fig. 5 for December 1956. During the period 18-22 December 1956, the mean 700 mb map (Green 1956) shows a low pressure system over eastern Alaska. This system allowed a breakup of the inversion with sudden warming occurring at Fort Yukon and also at Circle on the 18th. Previous warming at McKinley Park on the 11th, and at Bettles and Tanana on the 13th, however, did not reach the Yukon flats which remained at low and falling temperatures until the 18th. Finally, following a further cold period, general substantial warming occurred in the final week of the month with advection of warmer air across the whole region at moderately strong southerly gradients. Under these conditions of strong mixing, temperatures at all the low level stations in the region rapidly rose to similar values. Also shown in Fig. 5 is the course of daily minimum temperature at Fort Yukon in December 1917, the coldest month 


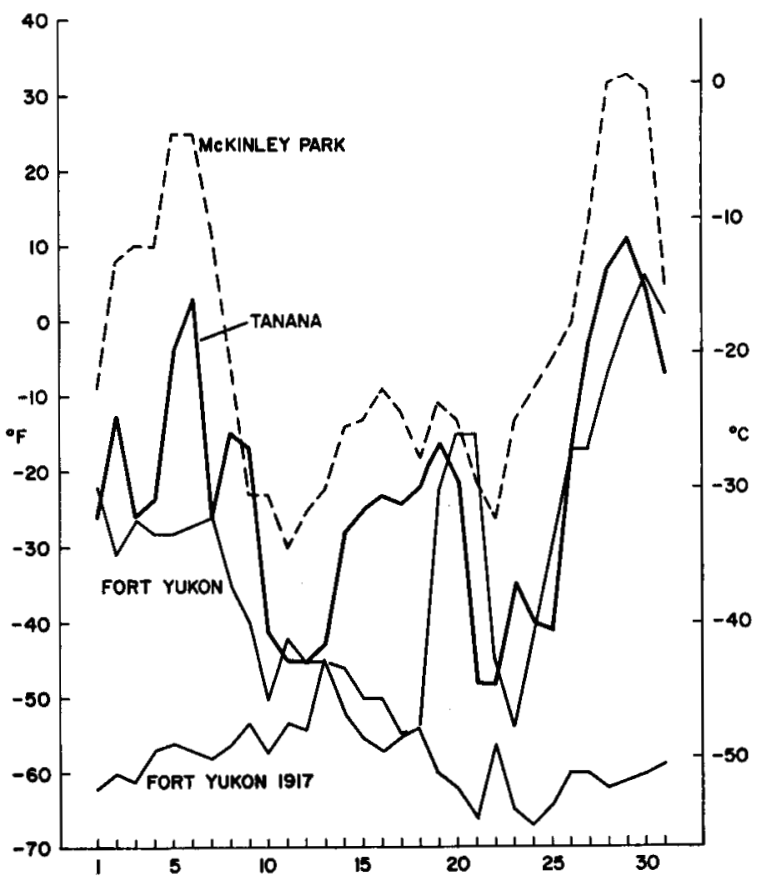

FIG. 5. Daily maximum temperatures for December 1956 at 3 stations in interior Alaska. Daily minimum temperatures for December 1917 are also shown for Fort Yukon.

on record at this station. This represents a case when apparently no substantial disturbance of the surface inversion took place and low temperatures were maintained despite considerable warming periods at Fairbanks and Tanana during the same period.

During December 1960, mean temperatures on the Yukon flats were 30 deg. F. warmer than in the cold year of 1956 and the mean average sea level chart for this month (Gelhard 1961) shows a moderately strong $S$ to SE gradient across

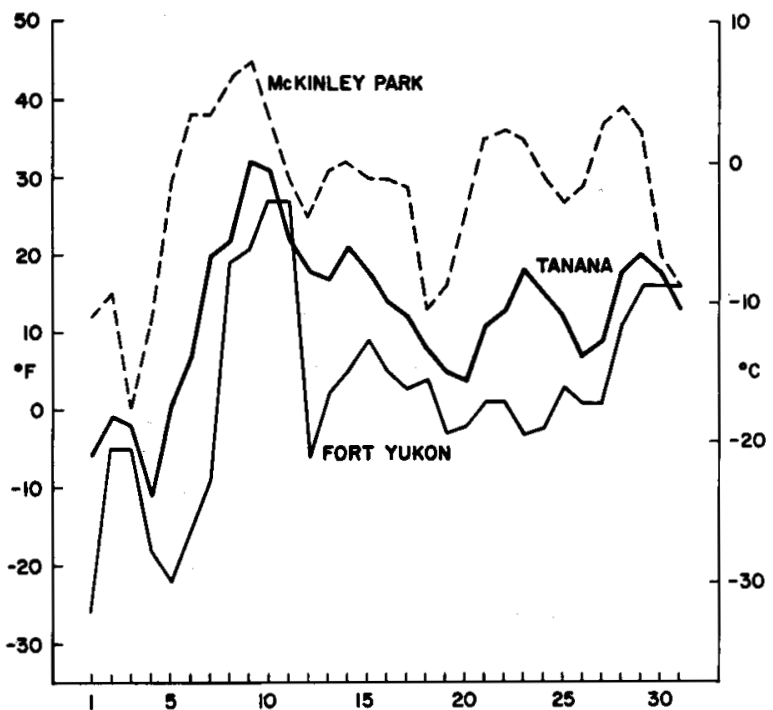

FIG. 6. Daily maximum temperatures for December 1960 at 3 stations in interior Alaska. 
Alaska. Under these circumstances (Fig. 6) the daily maximum temperatures tend to follow more in phase with each other at the three stations than in the colder months; conditions are, of course, much warmer, and the variations due to location of the stations are minimized.

It should be noted that mean temperatures in the interior Alaskan basin, even in the lower valleys, are not directly connected solely with elevation, e.g., average maximum, mean, and minimum temperatures recorded in the winter months at Fort Yukon (elevation 419 feet) are all colder by $8 \mathrm{deg}$. to $12 \mathrm{deg}$. F. than at Tanana (elevation 232 feet). Two local factors appear to be important in the occurrence of low winter temperatures on the broad part of the Yukon flats as exemplified by the observations at Fort Yukon and to a lesser degree at Circle.

1) The wide expanse of relatively flat and low-lying surface is ideally suited to the development of substantial low level temperature inversions in winter when the radiation balance of the surface is strongly negative. The area is sufficiently broad to prevent significant disturbance of the inversion once it is established by such local effects as perturbation by katabatic drainage from the surrounding hills. In this way it differs considerably from locations in the narrower parts of the Yukon Valley, from almost the whole of the Tanana Valley, and from stations such as Bettles which are located close to the southern slopes of the Brooks Range.

2) The flats are almost entirely encircled by a mountain mass of considerable elevation, which is highly effective in preventing the weaker low level synoptic scale weather systems from invading the basin. In this way, the area differs from most of the rest of the interior of Alaska, which is subject to varying degrees of influence, particularly by weather systems moving in from the southwest and even by such extensive channelling of strong winds through the mountain passes as has been described by Ehrlich (1953) and Mitchell (1956) for the mid-Tanana Valley.

Such local effects must be added to the primarily important factors due to the large-scale atmospheric circulation.

\section{RELATION TO GENERAL CIRCULATION CHARACTERISTICS}

The most important features contributing to the low mean winter temperatures in central Alaska are to be found in studies of the general circulation of the high latitudes of the Northern Hemisphere over a long period of years. Maps published by Keegan (1958) show the very high percentage frequency of anticyclones in eastern Alaska and the Yukon Territory in the winter months - a percentage which, for that period of study, exceeds that of the other maxima in the hemisphere, namely those over northern Greenland and central Siberia. By contrast, the frequency of cyclones is low here, forming part of an extensive minimum cyclonic frequency region extending from central Siberia across the Bering Sea and east to the Yukon. The most frequent tracks of synoptic scale systems in winter (Klein 1957) show principal tracks of anticyclones moving through central Alaska and southeastward into Canada, while the two principal tracks of cyclones are directed eastward along the Alaskan arctic coast, and from the Aleutians to 
the Gulf of Alaska, avoiding the interior of the State. An earlier study by Bodurtha (1952) shows a marked maximum of anticyclogenesis over the Yukon Territory, and the intense Siberian anticyclone extends eastward from time to time over the northwest of North America and may form detached cells over Alaska and the Yukon.

All these processes result in a high frequency of stable, calm, and cloudless conditions over central Alaska in winter, leading to the development of strong low-level inversions as the radiational cooling of the earth's surface proceeds under ideal conditions.

The most significant variations in mean temperature from month to month, as indicated by the graphs of Fig. 3, are associated with the changes in the planetary scale circulation pattern of the entire hemisphere at high latitudes and may be described in terms of the departures from the "mean" charts for particular months which have been produced by Namais (1958) and others; e.g., in the very warm month of December 1960, which has been discussed above, the mean $700 \mathrm{mb}$ chart (Gelhard 1961) shows mean southerly flow across the State, with windspeeds 3 to $5 \mathrm{~m} . \mathrm{s}^{-1}$ above average. It is interesting to note that this month provides a good example of a frequently occurring situation viz., a period when very warm winter temperatures in central Alaska are associated with extremely cold conditions in the eastern half of Canada and the contiguous United States. This is due to the location and the degree of development of the major ridge in the upper westerlies near the west coast of the continent and over the Yukon Territory, and the corresponding trough downstream with its axis lying from the Canadian archipelago to the south and southeast of Hudson Bay.

By contrast the cold year of 1956 is associated with a light northerly circulation in the mean at $700 \mathrm{mb}$, though with large variations from week to week, the windspeeds being close to normal.

Even in these extreme years, however, the departures from normal of the geopotential of the $700 \mathrm{mb}$ monthly mean chart in the northwest Pacific and North America region are not excessive.

Examination of monthly mean $700 \mathrm{mb}$ charts for the period between 1957 and 1967 indicates that often quite large variations in monthly mean temperature may occur without basically dissimilar mean circulation patterns. It appears that the existence of a slightly stronger mean wind flow in the lowest levels of the free atmosphere (and reflected in the $700 \mathrm{mb}$ mean windspeed) may be sufficient to cause this frequent destruction of the surface inversion and the mixing of warmer air to the surface. If such destruction of the inversion occurs often during the month, the resulting mean temperature is frequently well above average even though the major circulation features are not markedly abnormal.

\section{CONCLUSION}

The Yukon Flats, forming a secondary basin within the major basin of interior Alaska are protected to the greatest degree from disturbance of a winter climate controlled essentially by the strongly negative radiation balance of those months.

It is interesting to note that it is this area (an extent of some 10,850 square 
miles) that would be flooded to a depth of 100 to 400 feet if the project for the construction of the Rampart Dam proceeds to completion (Cooke 1964). The influence of such a large body of water on the climate might be considerable. In late fall, conditions might well be milder and the onset of very low temperatures delayed as the lake would act as an active heat source until it eventually froze over. In winter, while conditions could be expected to be similar to the present, a further contribution of heat to the surface would be available from the water beneath the ice and slightly milder temperatures at the surface might be expected. In the spring once the ice cover had broken from the surface the strong contrast between heated land and cooler water would result in the production of lake breeze effects and possibly lead to significant weather development.

Cyclonic influence over Siberia's Lake Baikal is marked in the spring and Great Slave and Great Bear Lakes in northern Canada are well known as sites for the development of storms (Wilson 1967). Analogous effects might be expected if an artificial lake were developed over the Yukon Flats. The development of summer thunderstorms in this region is already frequent and the data of Reed and Kunkel (1960) show a high frequency of fronts over the region in summer. The presence of a large body of water contrasting with land subject to long hours of summer heating would be likely to sharpen frontal contrasts and lead to enhanced cloud development and increased precipitation. The extent of such effects is, however, difficult to predict quantitatively.

\section{ACKNOWLEDGEMENT}

This work was supported by National Science Foundation Grant GA-900.

\section{REFERENCES}

BENSON, c. s. 1965 . Ice fog: low temperature air pollution. College: University of Alaska Geophysical Institute UAG R-173. 78 pp.

BODURTHA, F. T. 1952. An investigation of anticyclogenesis in Alaska. Journal of Meteorology, 9: 118-25.

COOKE, A. 1964. The Rampart Dam proposal for Yukon River. Polar Record, 12: 277-80.

EHRLICH, A. 1953. Note on local winds near Big Delta, Alaska. Bulletin of the American Meteorological Society, 24: 181-82.

GELHARD, R. G. 1961. The weather and circulation of December, 1960 - an unusually cold month in the United States. Monthly Weather Review, 89: 109-14.

GREEN, R. A. 1956 . The weather and circulation of December, 1956 - a month with large weekly fluctuations. Monthly Weather Review, 84: 444-51.

KEEGAN, T. J. 1958. Arctic synoptic activity in winter. Journal of Meteorology, 15: 513-521.

KLEIN, W. H. 1957. Principal tracks and mean frequencies of cyclones and anticyclones in the Northern Hemisphere. U.S. Weather Bureau Research Paper No. 40.

LILJEQUIST, G. H. 1964. Refraction phenomena in the polar atmosphere (Maudheim $71^{\circ} 03^{\prime} \mathrm{S}$. $10^{\circ} 56^{\prime}$ W.). Norwegian-British-Swedish Antarctic Expedition 1949-52. Scientific Results. Vol. II part 2B. pp. 91-120.

MITChelL, J. M. 1956. Strong surface winds at Big Delta, Alaska. Monthly Weather Review, 84: $15-24$. 
NAMAIS, J. 1958. Synoptic and climatological problems associated with the general circulation of the Arctic. Transactions of the American Geophysical Union, 39: 40-51.

REED, R. J. and B. A. KUNKEL. 1960. The arctic circulation in summer. Journal of Meteorology, 17: 489-506.

vowinckel, E. and S. ORvig. 1967. The inversion over the Polar Ocean. World Meteorological Organization Technical Note No. 87. pp. 39-59.

WATSON, C. E. 1959. Climates of the States - Alaska. U.S. Weather Bureau. 24 pp.

WEXLER, H. 1936. Cooling in the lower atmosphere and the structure of polar continental air. Monthly Weather Review, 64: 122-36.

WILsoN, c. 1967. Introduction: Northern Hemisphere 1, Cold Regions Science and Engineering. Part I: Environment, Section A-3: Climatology. Hanover: U.S. Army Corps of Engineers, Cold Regions Research and Engineering Laboratory. 141 pp. 